\title{
THE QUANTITATIVE AND QUALITATIVE ANALYSIS OF LARVAE HAEMOLYMPH PROTEIN IN BOTH SEXES OF SILKWORM, Bombyx mori L.
}

Eid, M. A.; S. A. Al-Otaibi; S. A. S. EL-Maasarawy and M.R. Abo- AL-Ela

Dept. Economic Entomology and Pesticides, Fac. Agric. Cairo Univ. Giza, Egypt.

\begin{abstract}
The silkworm, Bombyx mori L. has an economic importance in sericulture. Our results indicate that the average fresh cocoon, pupal and cocoon shell weights in females are significantly heavier than those in males. Also, the average haemolymph protein concentration of the last larval instar was significantly higher in females than that in males. The percentage elevation in females was $31.7 \%$ than males. Analysis of electropherogram from the haemolymph indicated the presence of 13 negatively charged proteins in females and 11 bands in males. Only one band with a molecular weight of $75.536 \mathrm{KDa}$ was common and shared by both females and males. This band represent $35 \%$ of the total haemolymph bands in males and $13.8 \%$ only in females. The other 22 bands are completely different in males and females.
\end{abstract}

\section{INTRODUCTION}

The domesticated silkworm, Bombyx mori L. has long been used as a model system for basic studies because of its large body size, ease of rearing in the laboratory, and economic importance in sericulture. Some early work suggested the proteins were sex-specific and found only in females but small amounts of the same proteins in males of some lepidopteran species (Wyatt, 1961). Thousands of practical breeding stocks are optimized by controlled breeding and selection for economically important quantitative traits such as growth rate, cocoon size, silk filament quality and disease resistance and then hybridized for silk production (Xu et al., 2002). The total protein concentration in the haemolymph increases rapidly and reaches the maximum in the full grown larvae of B. mori, Samia cynthia, Phormia regina and Pieris brassicae (Price, 1973). Insect haemolymph contains a wide variety of different proteins (Kansot et al., 1990). Many protein bands can be

detected by electrophoresis, and these change with physiological state, sex, age and other factors. In general, qualitative changes of the protein pattern are less dramatic compared to the increase in total concentration. The aim of this work is to evaluate the quantitative and qualitative nature of mature instar larva haemolymph protein of $B$. mori male and female. 
Eid, M. A. et al.

\section{MATERIALS AND METHODS}

\section{Quantitative analysis:}

\subsection{Cocoons weight:}

Bombyx mori larvae were reared under lab conditions in the department of economic entomology Faculty of agriculture , Cairo University during the Spring season of 2006. The larvae were fed on fresh mulberry leaves, Morus alba until pupation and spinning their cocoons.

After 9 days from cocooning thirty cocoons from each sex were weighed separately and average weight for each was calculated. The cocoons after being sexed and weighed pupae of each sex were removed and weighed separately, then the average of each was calculated.

\subsection{Cocoon shell weight:}

The previous cocoons, after removing the pupae and cleaning them from exuviae, were weighed and the average was calculated.

\subsection{Cocoon shell ratio:}

Cocoon shell ratio of each sex were calculated as follows Weight of cocoon shell $\quad \times 100$

Weight of cocoon

\section{Qulitative analysis:}

The haemolymph was collected from a punctured proabdominal leg of healthy last instar larvae of both sex in sterile test tubes with a small crystal of pheylthio-urea to prevent the sample melanization.

\subsection{Total protein concentration:}

It was estimated according to Henry (1964). This method depends on protein forms a colored complex with cupric ions in an alkaline medium.

\section{Reagents:}

$\begin{array}{llll}\text { R1 } & \text { Protein standard } & 6 & \mathrm{~g} / \mathrm{d} 1 \\ & \text { NaOH } & 0.6 & \mathrm{~N} \\ \text { K2 } & \text { K-Na-tartarate } & 18 & \mathrm{~m} \mathrm{~mol} / 1 \\ & \text { Pot. lodide } & 12 & \mathrm{~m} \mathrm{~mol} / 1\end{array}$

Biuret reagent cupric sulfate

6

\section{Procedure:}

The wave length is $546 \mathrm{~nm}$ and zero adjustment is reagent blank. Three main tubes $(2.5 \mathrm{ml})$ were prepared as follow; one blank, one standard $50 \mu \mathrm{l} \mathrm{nad}$ the last one is sample $40 \mu \mathrm{l}$. The tubes were mixed and incubated for 5 minutes at $20-25 \stackrel{\circ}{ } \mathrm{C}$. The total protein concentration calculated as follow

$$
=\frac{\text { Absorbance of sample }}{\text { Absorbance of standard }} \times 6=\mathrm{g} / \mathrm{dl}
$$

Sera samples were individually isolated by centrifugation at $3000 \mathrm{rpm}$ for 15 minutes at $4 \stackrel{\circ}{\circ}$ in a cooling centrifuge (Eppendorf, Germany). 


\subsection{Electrophoresis:}

Separation of proteins from sera sample was carried out by the application of SDS_PAGE method (Laemmli, 1970). The gel solution contained ammonium persulphate $(0.2 \%) 20 \mathrm{ml}$, acrylamide solution $30 \%$ acrylamide, 0.82 Bis acrylamide $15 \mathrm{ml}$, Tris $(1.5 \mathrm{M}$ tris adjusted to $\mathrm{pH} 9$ with $\mathrm{Hcl}) 7.5 \mathrm{ml}$ and $20 \% \mathrm{w} / \mathrm{v}$ SDS $0.33 \mathrm{ml}$. These ingredients were diluted to a final volume of $60 \mathrm{ml}$ with distilled water and polymerized with temed (N1 N1 $\mathrm{N} 1 \mathrm{~N}$-Tetraethyl $1: 2$-diaminoethane). Sample was prepared by mixing $4 \mathrm{ml}$ glycerol, $1.6 \mathrm{ml}$ SDS (10\%), $0.4 \mathrm{ml}$ beta-mercapto-ethanol and $0.2 \mathrm{ml}$ bromophenol blue $(0.05 \mathrm{M} / \mathrm{V})$. Then, sample of $15 \mu \mathrm{l}$ were carefully layered on the gel top under the running buffer ( $15 \mathrm{~g}$ tris base, $72 \mathrm{~g}$ glycine and $5 \mathrm{~g}$ SDS dissolved in one liter distilled water). Gels were run at $4 \stackrel{\circ}{\circ} \mathrm{C}$ and $\mathrm{mA}$ current for $4-5$ hours. They were washed, dried and stained for about 5 minutes with $0.1 \%$ silver stain (Nestereko et al, 1994). Scanning was applied using gel pro-analyzer software (Version 3.0, USA, 1998), Media Sci Image densitometry (700 Bio-Rad). The similarity coefficient was calculated according to Nei and Li (1979) and Lynch (1990).

\section{RESULTS AND DISCUSSION}

\section{Quantitative analysis:}

\subsection{Cocoon, pupal and cocoon shell weights:}

As shown in Table (1), the obtained results indicate that the average fresh cocoon weight in females $(1.369 \mathrm{gm})$ is significantly heavier than that in males $(1.1 \mathrm{gm})$. Moreover, heavier cocoon shells of females $(0.259 \pm 0.01$ $\mathrm{gm})$ give larger quantity of silk fibers than cocoon shell of males $(0.247 \pm 0.01$ $\mathrm{gm})$. The ratio of the cocoon shell weight to the total cocoon weight of females was 15.68 while that of males was (22.198). The pupal weight was significantly higher in females $(1.132 \pm 0.02 \mathrm{gm})$ than that of males $(0.846 \pm$ $0.03 \mathrm{gm}$ ). Our results indicate that cocoon, pupa and cocoon shell weights in both sexes were positively correlated with each other at $(P \geq 0.05)$. Cocoon, pupa and cocoon shell ratio is very important feature for cocoon quality and there is a full agreement that heavier cocoon gives heavier pupae and heavier cocoon shells and larger quantity of silk fibers.

Table (1). Pupal, cocoon and cocoon shell weights (in gram) and cocoon shell ratio of Bombyx mori males and females.

\begin{tabular}{|c|c|c|c|c|c|c|c|c|}
\hline & \multicolumn{2}{|c|}{ Pupal weight } & \multicolumn{2}{c|}{ Cocoon weight } & \multicolumn{2}{c|}{$\begin{array}{c}\text { Cocoon shell } \\
\text { weight }\end{array}$} & \multicolumn{2}{c|}{$\begin{array}{c}\text { Cocoon shell } \\
\text { ratio }\end{array}$} \\
\cline { 2 - 9 } & Male & Females & Male & Females & Male & Females & Male & Females \\
\hline Means & 0.846 & 1.132 & 1.1 & 1.396 & 0.247 & 0.259 & 22.24 & 15.68 \\
\hline S. D. & 0.03 & 0.02 & 0.03 & 0.04 & 0.01 & 0.01 & & \\
\hline
\end{tabular}

\subsection{Total protein concentration:}

Data in Table (2) show that the average haemolymph protein concentration of the fifth instar larvae was significantly higher in females $(4.91 \pm 0.91)$ than that in males $(3.72 \pm 0.54 \mathrm{gm}$ protein/ $\mathrm{d} 1 /$ haemolymph). 
Eid, M. A. et al.

Enan and Ali (1987) and Burr and Hunter (1969) showed that RNA and DNA contents were higher in females than in males of Oxycarenus hyalinipennis and Drosophila melanogaster. This means that there is a close relationship between the synthesis of the amount of total protein and the nucleic acid contents in the cell, and specific patterns of protein synthesis are correlated with changes in gene activity at different phases of the male and female life cycle. The total protein concentration in the haemolymph increases rapidly and reaches the maximum in females full grown larvae $(5.07 \pm 1.11 \mathrm{gm} / \mathrm{d} 1)$. Changes in haemolymph and fat body protein levels probably reflect the balance between the synthesis, storage, transport and degradation of structural and functional proteins during ontogeny, as well as a response to particular ecological and physiological conditions (Florkin and Jeuniaux, 1974).

Table (2). Effect of sex on total haemolymph protein concentration of fifth larval instar of Bombyx mori.

\begin{tabular}{|c|c|c|c|}
\hline Rep. No. & Sample size & $\begin{array}{c}\text { Male larvae } \\
\text { Mean } \pm \text { S.D. } \\
\text { (gm/d1) }\end{array}$ & $\begin{array}{c}\text { Female larvae } \\
\text { Mean } \pm \text { S.D. (gm/d) }\end{array}$ \\
\hline 1 & 10 & $3.86 \pm 0.80$ & $5.07 \pm 1.11$ \\
\hline 2 & 10 & $3.72 \pm 0.40$ & $4.91 \pm 0.90$ \\
\hline 3 & 10 & $3.58 \pm 0.43$ & $4.75 \pm 0.72$ \\
\hline Mean & & $3.72 \pm 0.54$ & $4.91 \pm 0.91$ \\
\hline
\end{tabular}

Ten larvae were assayed per sample, ten samples in each replicate.

\section{Qualitative analysis:}

Analysis of electropherogram from the haemolymph indicated the presence of 13 negatively charged proteins in females and 11 bands in males. Only one band (No. 17 with a molecular weight of $75.536 \mathrm{KDa}$ ) was common and shown to be shared in the protein profiles of both males and females. This band represent $35 \%$ of total protein bands in males while it represent only $13.8 \%$ in females of total protein bands. The electrophoretic profile of native proteins, as examined by SDS-PAGE, recorded a wide range of molecular weights ranging between 210.17 and $26.23 \mathrm{KDa}$ (Fig. 1 and Table 3). The similarity coefficient was calculated according to Nei and $\mathrm{Li}$ (1979) as follows:

$$
\begin{aligned}
& =\frac{2 \times \text { number of sharing protein bands }}{\text { Number of protein bands in samples A+B }}=\frac{2 \times 1}{11+13}=\frac{2}{24} \\
& =0.08
\end{aligned}
$$

This means that the similarity coefficient was extremely low (0.08) between the two sexes of Bombyx mori. Minor qualitative differences in the blood proteins of the two sexes in various insects were recorded by Stephan and Steinhaver (1957) and Wyatt (1961). 
J. Agric. Sci. Mansoura Univ., 33 (3), March, 2008



Marker $\bigcirc^{\pi} \stackrel{\bigcirc}{+}$

Fig. (1): SDS - PAGE analysis of haemolymph of mature B.mori L. larvae males and females. MW markers in $(\mathrm{KDa})$ are shown in the for right lane.

Table (3).Haemolymph protein bands of fifth larval instar of Bombyx mori males and females.

\begin{tabular}{|c|c|c|c|c|c|}
\hline Band No. & Mol. Weight (KDa) & \multicolumn{2}{|c|}{ Males amount (\%) } & \multicolumn{2}{|c|}{ Females amount (\%) } \\
\hline 1 & 210.17 & + & 5.17 & - & - \\
\hline 2 & 202.14 & - & - & + & 5.10 \\
\hline 3 & 186.76 & + & 10.60 & - & - \\
\hline 4 & 184.94 & - & - & + & 5.19 \\
\hline 5 & 181.06 & - & - & + & 4.70 \\
\hline 6 & 166.15 & - & - & + & 3.85 \\
\hline 7 & 164.74 & + & 4.54 & - & - \\
\hline 8 & 154.08 & - & - & + & 4.63 \\
\hline 9 & 149.37 & + & 3.93 & - & - \\
\hline 10 & 134.80 & - & - & + & 4.54 \\
\hline 11 & 133.38 & + & 3.59 & - & - \\
\hline 12 & 123.52 & - & - & + & 4.24 \\
\hline 13 & 118.90 & + & 4.00 & - & - \\
\hline 14 & 108.50 & - & - & + & 4.61 \\
\hline 15 & 95.689 & + & 6.69 & - & - \\
\hline 16 & 86.458 & + & 3.95 & - & - \\
\hline 17 & 75.536 & + & 35 & + & 13.80 \\
\hline 18 & 69.131 & - & - & + & 11.60 \\
\hline 19 & 59.591 & - & - & + & 11.70 \\
\hline 20 & 53.608 & + & 17.40 & - & - \\
\hline 21 & 49.634 & - & - & + & 15.20 \\
\hline 22 & 30.212 & - & - & + & 9.41 \\
\hline 23 & 26.234 & + & 5.12 & - & - \\
\hline Sum & & & 99.90 & & \\
\hline In lane & 100 & & 100.00 & & \\
\hline
\end{tabular}




\section{REFERENCES}

Burr, M. J. and A. S. Hunter (1969). Effect of temperature on Drosophila weight and water, protein and RNA content. Comp. Biochem. Physiol., 29: $647-652$.

Enan, R. A. and S. M. Ali(1987). Effect of different temperature on certain physiological aspects of the cotton seed bug, Oxycarinus hyalinipennis Costa. Ain Shams Sci. Bull., 8: 321-328.

Florkin, M. C. and C. H. Jeuniaux (1974). Haemolymph composition in the physiology of insecta. Ed. Rockstein, M. S. $2^{\text {nd }}$ edition, pp. $255-307$. New York, Academic Press.

Henry, B. (1964). DNA, RNA and Protein synthesis after acute, severe blood loss: a picture of erythropoiesis at the combined morphological and molecular levels. Ann. NY Acad. Sci., 119:523-39.

Kanosot, M. R.; J. K. Kawooya; J. H. Law; R. O. Ryan; M. C. Van Huesden and R. Ziegler (1990). Insect haemolymph proteins. Adw. Insect Physiology, 22: 299 - 396.

Laemmli, U. K. (1970). Cleavage of structural proteins during the assembly of the head of bacteriophage T4. Nature, 227: $680-685$.

Lynch, M. (1990). The similarity index and DNA fingerprinting. Mol. Bio. Evol., 5: $584-599$.

Nei, M. and W. H. Li (1979). Mathematical models for studying genetic variation in terms of restriction endonucleases. Proc. Nat. Acad. Sci. (USA), 76: 5269 - 5273.

Nesterenko, M. V.; M.Tilley and S. J. Upton(1994). A simple modification of Blum's silver stain method allows for 30 minute detection of proteins in polyacrylamide gels. J Biochem. Biophys. Meth., 28(3):239-42.

Price, G. M. (1973). Biol. Rev. Cambridge Philos. Soc. 48, 33. Protein and nucleic acid metabolism in insect fat body. J. Biol. Rev. Cambridge Philos. Soc., 48(3), 333-75.

Stephen, E. P. and A. L. Steinhauer (1957). Sexual differences in blood proteins. Physiol. Zool., 30:114-20.

Wyatt, G. R. (1961). The biochemistry of insect haemolymph. Ann. Rev. Ent., 6: $75-102$.

Xu, M. K.; Y. Y. Chen and Y. H. Jiang (2002). A brief report on the breeding of special silkworm varieties " xinniao and mingre". Sericologia, 42: 425 $-429$. 
Bombyx Mori التحليل الكمي والنوعي للبروتين في دم يرقات دودة الحرير التوتيـة



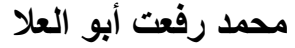
قسم الحشرات الاقتصادية والمبيدات ـ كلية الزراعة - جامعة القاهرة ـ الجيزة ـ مصر .

تعتبر دودة الحرير التوتية . Bombyx mori L ذات أهية اقتصادية في إنتاج الحرير

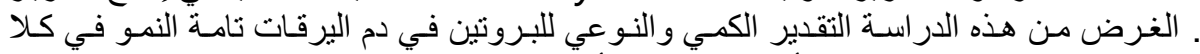

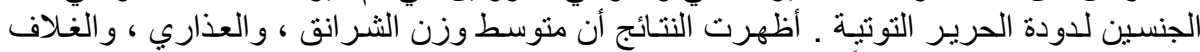

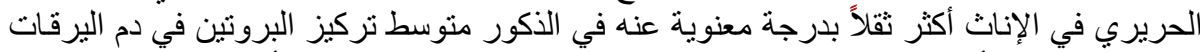

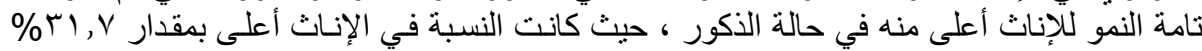

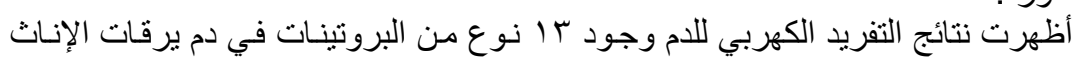



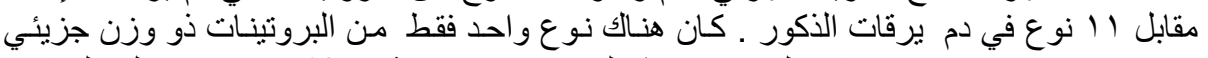

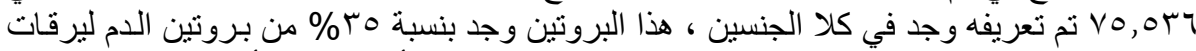

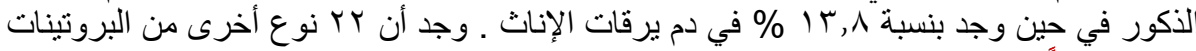
اختلفت تماماً في الذكور عن الإناث . 
Eid, M. A. et al.

2245

2246

2247

2248

2249

2250

2252

$-2251$

2252 